\title{
UTILIZATION OF RUBBER SEED MEAL AS A PROTEIN SUPPLEMENT IN BROILER FINISHER RATIONS.
}

\author{
I. O. A. ADELEYE and A. A. ODUNSI \\ Department of Animal Science \\ University of Ibadan, Nigeria \\ (Received 19 April 1990; accepted 10 September 1990)
}

\begin{abstract}
A feeding triai was conducted to evaluate the performance of finisher broiler chicks fed diets containing different levels of partially defatted rubber seed meal as a replacement for groundnut cake. Four isocaloric and isonitrogenous diets (A, B, C and D) were formulated using groundnut cake (GNC) as the reference protein source; and 10,15 and $20 \%$ of the GNC in the control diet (A) were replaced with rubber seed meal ( $R S M$ ) in rations $B, C$ and $D$, respectively. No significant differences $(P>0.05)$ were observed in feed intake, growth rate, feed efficiency and protein efficiency ratio among the birds on the diffeent diets. However, the dressed weight and dressing percentage and total edible meat to bone ratio showed significarat $(P<0.05)$ differences. The results indicated that replacement of GNC with RSM at levels studied, did not significantly depress the perforranance of broiler finishers but was quite beneficial in terms of economics of production.
\end{abstract}

Key words: rubber seed meal, protein, broiler.

\section{INTRODUCTION}

Twe ses of animals whose production can contrios $c:$ rapidly to the available meat supplies on the short run are pigs and poultry. It has been observed (Hodgson, 1971,Babatunde, 1980) that poultry holds unique position in bridging the animal protein supply gap in developing countries for the fact that poultry can be reporduced much quicker than any other livestock, they are highly prolific and are good feed converters. Feed accounts for about 55 per cent of egg production and 65 per cent of broiler production (Oluyemi and Roberts, 1979). The major feed ingredients (cereals and pulses) are very expensive because they are also needed by humans as staple. In order to reduce the cost of poultry production therefore, the nutritional potentials of unconventional feed sources need to be investigated. One of such feed sources is rubber seed meal. Various studies (Fetuga et al., 1975; Panam et al., 1978 and Nwokolo et al., 1986) have suggested that rubber seed meal could be a potential source of vegetable protein in poultry diets. The present study was undertaken to investigate the effect of graded levels of partially defatted rubber seed meal in the finisher ration of broilers on performance in terms of feed intake, growth rate, feed efficiency and dressing percentage.

\section{MATERIALS AND METHODS}

A total of 500 White Rose broiler-type day-old chicks were raised to the age of 5 weeks on a commercial ration in which groundnut meal was used as the reference vegetable protein source. All necessary vaccinations and other medications were administered at the appropriate periods. At 5 weeks of age, 120 birds were selected and randomly distributed into 4 treatment groups each with two replicates. Each replicate consisted of 15 birds (i.e. 30 birds per treatment). Four isonitrogenous and iso-caloric rations were formulated as shown irt Table 1. The partially defatted rubber seed meal (RSM) used in this study was obtained from the Rubber Research Institute of Nigeria, Benin City. Ration A was the control and it consisted of groundnut cake (GNC) as the vegetable protein source. In rations $B, C$ and $D ; 10,15$ and $20 \%$ of the GNC in ration $A$ were replaced with the partially defatted RSM. In absolute values, the RSM constituted $0,5.36,8.04$ and $10.77 \%$ of the experimental rations $\mathrm{A}, \mathrm{B}, \mathrm{C}$ and $\mathrm{D}$ respectively.

All birds were fed and watered ad libitum under identical environmental and management conditions on concrete-floored pens littered with wood shavings as the bedding material. The birds were weighed at the commencement of the experiment and subsequently at weekly intervals. A record of feed consumption was also kept. At nine weeks of age, 2 birds per replicate were selected and put in 3-tier metabolic cages with facilities for individual feeding, watering and collection of droppings. The birds were maintained on their respective rations. Three days were allowed for adjustment, followed by a 4-day collec- 
TABLE 1: COMPOSITION OF EXPERIMENTAL. DIETS

\begin{tabular}{|c|c|c|c|c|}
\hline \multirow[b]{2}{*}{ ingredients (\%) } & \multicolumn{4}{|c|}{ Rations } \\
\hline & A & $\mathrm{B}$ & C & $\bar{D}$ \\
\hline$\overline{\text { Maize (Yellow) }}$ & 59.75 & 56.79 & 55.31 & 53.78 \\
\hline Groundnut cake & 24.00 & 21.60 & 20.40 & 19.20 \\
\hline Rubber seed meal & 0 & 5.36 & 8.04 & 10.77 \\
\hline Fish meal & 2.50 & 2.50 & 2.50 & 2.50 \\
\hline Dry brewers grains & 10.00 & 10.00 & 10.00 & 10.00 \\
\hline Bone meal & 2.00 & 2.00 & 2.00 & 2.00 \\
\hline Oyster shell & 1.00 & 1.00 & 1.00 & 1.00 \\
\hline Vitamin/mineral mix ${ }^{*}$ & 0.50 & 0.50 & 0.50 & 0.50 \\
\hline Salt & 0.25 & 0.25 & 0.25 & 0.25 \\
\hline TOTAL & 100.00 & 100.00 & 100.00 & 100.00 \\
\hline Calculated C.P.(\%) & 20.0 & 20.0 & 20.0 & 20.0 \\
\hline M.E. (Kcal/kg) & 2.95 & 2.95 & 2.95 & 2.95 \\
\hline
\end{tabular}

*Vitamin/mineral mix provided (per $\mathrm{kg}$ ration):

Vit. A; $9,000,000 \mathrm{IU}$; Vit D3, 1,250,000 IU; Vit E, 7,000 IU;

Riboflavin, 6,000 mg; Vit B3, 22,000 mg; Vit B5, 14,000 mg;

Lysine, 120,000 mg; Methionine, 65,000 mg; Choline Chlorine,

$240,000 \mathrm{mg}$; Mn 60,000 mg; Fe 35,000 mg; Cu 5,000 mg; 12

$1,100 \mathrm{mg}$; Se $100 \mathrm{mg}$; Antioxidant, $125,000 \mathrm{mg}$.

t1on period. Daily feed consumption was recorded, and droppings were collected daily, wrapped in tin foil and dried in the oven at $80^{\circ} \mathrm{C}$ for 48 hours. The total dried droppings collected for each treatment group was pooled, milled and stored for chemical analysis later. Proximate chemical composition of feeds and droppings, as well as the partially defatted RSM was carried out using A0AC (1980) procedures while the gross energy was determined using the Gallenkamp Ballistic Oxygen Bomb Calorimeter.

The experiment was terminated when the birds were 10 weeks sold. At termination, 2 birds per replicate were selected for carcasss evaluation. The birds were fasted overnight but had access to water. They were weighed the following morning and then slaughtered by the external cut throat method and thoroughly bled. The carcasses were defeathered, eviscerated and cleaned. The organs were carefully removed and weighed. The carcass was then cut into different parts: thigh, drumstick, breast, neck, wing and back and weighed separately. Weight of raw edible meat was obiained by careful removal of all nuscles from the bones.

Calculations of metabolizable energy (M.E.), protein efficiency ratio (P.E.R.) and economics of production were made and all data were analyzed using the Completely Randomized Design procedure Steel and Torrie, 1960) while significant differences between treatment means were determined using Duncan (1955) multiple range test.

\section{RESULTS}

The chemical composition of the experimental diets and the partially defatted RSM are shown in Table 2. The crude protein content of the control diet $(22.66 \%)$ was slighly higher than those of diets containing RSM $(22.62,21.09$ and 21.09 for diets B. C and D respectively). There was a progressive decrease in the $C P$ and ash content as the level of RSM increased. The other extract and the crude fibre contents on the other hand increased as the level of RSM increased. 
TABLE 2: CHEMICAL COMPOSITION OF EXPERIMENTAL DIETS AND RUBBER SEED MEAL (DM BASIS)

\begin{tabular}{|c|c|c|c|c|c|c|}
\hline \multirow[b]{2}{*}{ Constituents } & & \multicolumn{4}{|c|}{ Rations } & \multirow{2}{*}{$\begin{array}{l}\text { Rubber } \\
\text { seed } \\
\text { meal }\end{array}$} \\
\hline & & $A$ & $\bar{B}$ & $\mathrm{C}$ & D & \\
\hline Dry Matter (\%) & & 92.71 & 92.90 & 93.00 & 93.00 & 92.94 \\
\hline Crude Protein (\%) & ; & 22.66 & 22.62 & 21.09 & 21.09 & 18.05 \\
\hline Ether Extract (\%) & & 9.25 & 9.61 & 9.60 & 9.82 & 32.19 \\
\hline Ash $(\%)$ & & 4.67 & 4.17 & 3.54 & 3.34 & 2.81 \\
\hline Crude Fibre (\%) & & 3.25 & 3.52 & 3.68 & 4.31 & 3.89 \\
\hline N.F.E. (\%) & & 60.17 & 60.08 & 62.09 & 61.44 & 33.06 \\
\hline G.E. (Kcal/g) & & 4.24 & 4.18 & 4.18 & 4.24 & 5.33 \\
\hline
\end{tabular}

Data on performance characteristics of the experimental birds are presented in Table 3 . The average daily feed intake per bird was highest for treatment $\mathrm{A}$ ( $93.62 \mathrm{~g} /$ day) while the average daily feed intake was $92.65,91.41$ and $91.97 \mathrm{~g} /$ day for treatments $\mathrm{B}, \mathrm{C}$ and $\mathrm{D}$ respectively. The differences were not significant $(P>0.05)$. The average daily weight gains were $34.66,33.97,31.37$ and $32.24 \mathrm{~g} /$ day for treatments $A, B, C$ and $D$ respectively. At 10 weeks of age, the birds on treatment $A$ were the heaviest (1825.5g followed by those on diet B $(1814.5 \mathrm{~g})$ diet $D+756.5 \mathrm{~g})$ and diet $\mathrm{C}(1731.5 \mathrm{~g})$. The dif- ferences in weight gain and final liveweight were not significant $(\mathrm{P}>0.05)$. Birds on treatment $\mathrm{A}$ had the best feed efficiency $(2.70 \mathrm{~g}$ feed $/ \mathrm{g}$ gain) followed by treatments B (2.73), D (2.85) and C 2.91). The protein efficiency ratio was best for diet D (3.11) followed by diet B (3.09), diet A (3.02) and diet $C(2.93)$. The differences were not significant $(\mathrm{P}>0.05)$. No mortality was recorded throughout the experimental period.

The data on carcass characteristics are presented in Table 4 . The average dressed weight of birds on the control diet was $1393.05 \mathrm{~g}$ which was significantly $(\mathrm{P}<0.05)$ higher than

TABLE 3: PERFORMANCE CHARACTERISTICS OF BROILER FINISHERS FED THE EXPERIMENTAL DIETS

\begin{tabular}{lcccc}
\hline & \multicolumn{5}{c}{ Rations } \\
\cline { 2 - 5 } Parameters & $\mathrm{A}$ & $\mathrm{B}$ & $\mathrm{C}$ & $\mathrm{D}$ \\
\hline Number of birds & 30 & 30 & 30 & 30 \\
Experimental period (days) & 35 & 35 & 35 & 35 \\
Avg. Initial liveweight (g) & 612.5 & 625.5 & 633.5 & 628.5 \\
Avg. Final liveweight (g) & 1825.5 & 1814.5 & $17315^{\circ}$ & 1756.5 \\
Avg. Daily weight gain (g) & 34.66 & 33.97 & 31.3 & 32.24 \\
Avg. Daily feed intake (g) & 93.62 & 92.65 & 91.4 & 91.97 \\
Feed efficiency & 2.70 & 2.73 & 2.9 & 2.85 \\
P.E.R. & 1.79 & 1.76 & 1.76 & 1.80 \\
Mortality & 0 & 0 & 0 & 0 \\
M.E. (Kcal/g) & 3.02 & 3.09 & 2.93 & 3.11 \\
N2 retention (\%) & 85.45 & 85.78 & 84.85 & 85.74
\end{tabular}


those of diets B (1280.25g), C (1225.28g) and D $(1217.97 \mathrm{~g})$. Similarly, the dressing percentage of birds on diet $A$ was significantly $(\mathrm{P}<0.05)$ higher than those of diets B, C and D. However, both the dressed weight and dressing percentage of birds on diets B, C and D were not significantly $(P>0.05)$ different from one another. The average total edible meat was higher for diet $\mathrm{A}$ (1060.8g) followed by diets B $(977.2 \mathrm{~g})$, D $(943.6 \mathrm{~g})$ and $\mathrm{C}(938.7 \mathrm{~g})$ while the average total bone was highest for diet $\mathrm{D}(310.1 \mathrm{~g})$ followed by diets B (306.4g), C (298.5g) and A (272.2g). The differences were not significant $(P>0.05)$. The ratio of edible meat to bone was highest for birds on $\operatorname{diet} A(P<0.05)$, while those of diets $B, C$ and
$D$ were not significantly $(P>0.05)$ different from on another.

The cost of production are presented in Table 5. The feed cost per kilogram of control diet (A) was highest (N1.06). There was a progressive decrease in the feed cost as the level of RSM in the diets increased. Calculation of cost of feed per kilogram weight gain showed that diet B was the cheapest (N2.80). This was followed by diet $\mathrm{D}$ (N2.83), $\operatorname{diet} \mathrm{A}(\mathrm{N} 2.86)$ and $\operatorname{diet} \mathrm{C}(\mathrm{N} 2.94)$ in that order. The differences were however not significant $(\mathbf{P}>0.05)$.

TABLE 4: CARCASS CHARACTERISTICS OF BROILER FINISHERS FED THE EXPERIMENTAL DIETS

\begin{tabular}{|c|c|c|c|c|}
\hline \multirow{2}{*}{ Parameters } & \multicolumn{4}{|c|}{ Rations } \\
\hline & A & $B$ & C & $\mathrm{D}$ \\
\hline Liveweight (g) & 1825.5 & 1814.5 & 1731.5 & 1756.5 \\
\hline Dressed weight $(\mathrm{g})$ & $1393.05^{\mathrm{a}}$ & $1280.25^{b}$ & $1225.28^{b}$ & $1217.97^{b}$ \\
\hline Dressed wt. (\% of live wt. & t.) $76.31^{\mathrm{a}}$ & $70.56^{b}$ & $70.76^{b}$ & $69.34^{\mathrm{b}}$ \\
\hline Breast $(\mathrm{g})$ & 335.2 & 305.4 & 311.2 & 297.8 \\
\hline $\operatorname{Nec}(g)$ & 84.7 & 81.0 & 80.1 & 83.2 \\
\hline Wing (g) & 140.1 & 145.2 & 132.6 & 134.7 \\
\hline Back (g) & 255.4 & 277.1 & 270.4 & 260.5 \\
\hline Thigh $(g)$ & 201.4 & 188.5 & 180.6 & 185.1 \\
\hline Drumstic $(g)$ & 198.2 & 180.5 & 175.9 & 176.4 \\
\hline Abdominal fat pad $(\mathrm{g})$ & 38.2 & 42.8 & 44.2 & 48.3 \\
\hline Total edible meat $(\mathrm{g})$ & 1060.8 & 977.2 & 938.5 & 943.6 \\
\hline Total bone $\quad(g)$ & 272.2 & 306.4 & 298.5 & 310.0 \\
\hline Meat: bone ratio & $3.90^{\mathrm{a}}$ & $3.19^{b}$ & $3.14^{b}$ & $3.04^{b}$ \\
\hline Organs: Spleen (g) & 2.25 & 2.08 & 2.14 & 2.05 \\
\hline Gizzard $(g)$ & 35.79 & 36.56 & 38.76 & 39.68 \\
\hline Liver $(\mathrm{g})$ & 37.75 & 35.24 & 35.01 & 33.91 \\
\hline Lung (g) & 14.19 & 11.03 & 13.34 & 10.77 \\
\hline Heart $(g)$ & 9.25 & 9.98 & 9.50 & 9.22 \\
\hline Kidney (g) & 14.14 & 14.29 & 14.48 & 15.09 \\
\hline
\end{tabular}

$a, b$ Means with different superscript letters on the same row differ significantly $(P<0.05)$. 
ABLE 5: COST OF PRODUCTION AND EFFICIENCY OF THE EXPERIMENTAL DIETS

\begin{tabular}{lllll} 
& \multicolumn{3}{c}{ Rations } \\
\cline { 2 - 5 } Parameters & $\mathrm{A}$ & $\mathrm{B}$ & $\mathrm{C}$ & $\mathrm{D}$ \\
\hline Feed cost $(\mathrm{N} / \mathrm{kg})$ & 1.06 & 1.03 & 1.01 & 0.99 \\
Total feed intake/bird $(\mathrm{kg})$ & 3.28 & 3.24 & 3.20 & 3.22 \\
Cost of feed consumed/bird $(\mathrm{N})$ & 3.47 & 3.32 & 3.23 & 3.19 \\
Total weight gain/bird $(\mathrm{kg})$ & 1.21 & 1.19 & 1.10 & 1.13 \\
Cost of feed $/ \mathrm{kg}$ gain $(\mathrm{N})$ & 2.86 & 2.80 & 2.94 & 2.83
\end{tabular}

\section{DISCUSSION}

The crude protein content of $28.05 \%$ obtained for the partially defatted RSM in this study is similar to $28.63 \%$ reported by Nwokolo (1986) but slightly higher than $26.6 \%$ reported by Panam et al. (1978) and $26.7 \%$ by Toh and Chia (1986). The different crude protein valuess reported by various workers are due to the efficiency of oil extraction. The higher the amount of oll extracted, the higher the crude protein content of the meal. Although the crude protein contents of the diets vary slightly, the levels (21.0\%.22.62\%) were withiv the range recommended by various workers NRC, 1971; Olomu, 1976; Babatunde and Fetuga, 1976).

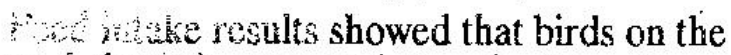
cont ${ }^{5}$ en $(5)$ consumed more feed than those on other diets. Perhaps, the levels of RSM used in the present study were not enough to significantly depress feed intake. Nwokolo et al. (1986) observed a significant reduction in feed intake when $50 \%$ of the dietary protein was supplied by RSM. In the present study, birds on diet A exhibited the best growth rate, followed by birds en diets containing 10, 20 and $15 \%$ RSM (diets $\mathrm{B}, \mathrm{D}$ and $\mathrm{C}$ respectively). The observed differences were not significant, indicating that the levels of RSM in the present study were not too high to cause significant growth rate depressions. The best feed efficiency was observed in birds on diet B (10\% RSM) followed by birds on $\operatorname{diets} A, D$ and $C$ in that order. The differences were not significant and the results agree with those of Panam et al. (1978) and Nwokolo and Akpakunam (1986). There was no mortality throughout the experimental period, suggesting that the birds were able to tolerate the levels of RSM used in this study.
Although, the control diet (A) gave the best meat to bone ratio, it is noteworthy that the RSM-containing diets (B and D) gave the best results in terms of cost of feed per kilogram liveweight gain. The results have indicated that RSM was efficiently utilized as GNC and where GNC is not easily available, comparable growth rate at cheaper production costs could be attained by its substitution with RSM at the levels studied. With about 200,000 ha of rubber plantation in Nigeria, and with estimated seed yield of about $100 \mathrm{~kg} / \mathrm{ha}$, the rubber estates in Nigeria have a potential to produce over 15,000 metric tonnes of seed per year. The defatted meal obtained from these seeds (Oluyemi et al., 1975) is capable of meeting up to $20 \%$ of Nigeria's need for protein concentrates in poultry nutrition.

\section{REFERENCES}

A.O.A.C. 1980 . Association of Official Analytical Chemists. Official Methods of Analysis, 12 th edition, Washington D. C.

BABATUNDE, G. M. 1980. The tottering Nigerian livestock sector: its problems and possibilities. Inaugural lecture, University of Ibadan.

BABATUNDE, G. Ma and FETUGA, B. L. A. 1976. Determination of the mirimum crude protein requirements of broitur staters and finishers in the tropics. Niger. J.Anim. Prod. 3: 126-138.

DUNCAN, D. B. 1955. Multiple range and multiple F-tests. Biometrics 11:1-42.

FETUGA, B.L.A.; BABATUNDE, G. M. and OYENUGA, V. A. 1975. The rotentials of para rubber seed meal as a protetra source in 
human and livestock feeding. Proc. 1st Afr. Nutr. Cong. University of Ibadan.

HODGSON, R. E. 1971. The place of animals in World Agriculture. J. Dairy Sci. 54: 445.

N.R.C. 1971. National Research Council. Nutrient Requirements of poultry: National Academy of Sciences, Washington D. C.

NWOKOLO, E. 1986. True protein digestibility, metabolizable energy content and toxicity of raw and processed rubber seed meal for pullet chicks. Proc. Industrial Utilization of Rubber Seed, latex and wood, Benin City 63-69.

NWOKOLO, E. and AKPAKUNAM, M 1986. Chemical and biological evaluation of Rubber seed meal. Proc. Industrial evaluation of Rubber seed, latex and wood, Benin City, 54-61.

NWOKOLO, E., DARREL, B. B. and JEONG, S. S. 1986. Assessment of nutritive value of rubber seed meal and oil in poultry diets. Poultry Sci, Abs. 65:99.
OLOMU, J. M., 1976. Determination of optimum protein and energy levels for broiler chicks in the tropics. Niger. J. Anim. Prod. 3: 250-257.

OLUYEMI, J. A. and ROBERTS, F. A. 1979. Poultry Production in Warm Wet Climates. Macmillan Press Ltd., London.

PANAM, A.; VENUGOPALAN, C. K.; URINY, A.K.K. 1978. Feeding value of rubber seed meal for laying hens. Indian J. Poultry Sci. 13: 139-143.

STELL, R.G.D. and TORRIE, J. H. 1960. Principles and Procedures of Statistics. McGrawHill Book Co. Inc., New York.

TOH, K. S. and CHIA. S. K. 1978. Nutritional value of rubber seed meal in livestock. Proc. Malaysian Soc. Anim. Prod., 337-344. 